УДК 378.016:33]:004.9](73)

(С) Сотніков Д. В., 2020 p.

https://orcid.org/0000-0001-5740-5808

https://doi.org/10.34142/23128046.2020.48.10

Д. В. Сотніков

\title{
ОСОБЛИВОСТІ ДІЯЛЬНОСТІ ЕКОНОМІЧНОГО ФАКУЛЬТЕТУ МАССАЧУСЕТСЬКОГО ТЕХНОЛОГІЧНОГО ІНСТИТУТУ
}

У статті здійснено аналіз особливостей діяльності економічного факультету Массачусетського технологічного інституту. Акцентовано увагу на тому, що університет відіграє ключову роль у розвитку багатьох галузей сучасної науки $i$ практики. Установлено, щцо значний внесок у розвиток економічного факультету на базі Школи гуманітарних, художніх $i$ соиіальних наук зробив Ф. Уокер - заслужений економіст, член Національної академії наук США, третій президент Массачусетського технологічного інституту. $У$ ході дослідження простежено навчальні завдання, що висуваються перед викладачами під час підготовки бакалаврів, магістрів та докторів філософії з економіки, окреслено фахові дисципліни (обов'язкові та вибіркові), визначено методи навчання, зокрема інтерактивні, наприклад, "case study», ділові ігри, господарські ситуаџї, робота над реальними проєктами державних службовиів чи приватних корпоращій, щзо використовуються як під час аудиторної, так $і$ самостійної роботи. 3'ясовано, що інститут впроваджує новітні методи викладання не лише в межах США, а й шляхом дистаниійного навчання, виходить на міжнародний рівень, зокрема за допомогою проєктів MIT OpenCourseWare, MITx ma MicroMasters. На підставі аналізу навчальних програм, щуо пропонуються на економічному факультеті, узагальнено компетениії випускників-економістів Массачусетського технологічного інституту. Досвід МТI показує, що сучасна економічна освіта США передбачає оволодіння освітніми ступенями бакалавра (Undergraduate level), магістра (Graduate level) ma доктора філософії (PhD). Підготовка фахівців економічного профілю полягає у вивченні таких дисииплін, як: політична економія, мікро- та макроекономіка, теорія ймовірності, статистика, економіко-математичне моделювання, економічне застосування теорії ігор, фінансові ринки, маркетинг, економічний розвиток, міжнародна економіка та багато інших. Серед провідних методів навчання визначено інтерактивні методи ("сале study», ділові ігри, господарські ситуачї̈, робота над бізнес-проєктами, ланч-семінари, польові обіди тощо).

Ключові слова: економічна освіта, економічний факультет, інформаційно-комунікаиійні технології, фахові дисиипліни, професійна підготовка, педагогічні підходи, інтерактивні методи навчання. 
Sotnikov D. V. The features of the activities of the Department of Economics of the Massachusetts Institute of Technology. The article discusses the features of the activities of the Department of Economics of the Massachusetts Institute of Technology. The attention is focused on the fact that the university is the key in the development of many branches of modern science and technology. It was established that the discoverer of the Department of Economics at the School of Humanities, Arts and Social Sciences was Francis Amasa Walker - honored economist, member of the National Academy of Sciences, third president of the Massachusetts Institute of Technology. The study traces the educational problems facing teachers in the preparation of undergraduates, graduates and Doctor of Philosophy in economics, identifies professional disciplines (majors and electives). During the teaching of economic disciplines, such approaches are applied: Chalk and Talk; Proficiency Approach; Peakonomics; Writing Intensive; Attention, Relevance, Confidence, and Satisfaction. Noted interactive teaching methods such as case study, business games, business situations, work on real projects of public servants or private corporations used both in classroom and independent work. It turned out that the university implements the latest teaching methods not only on campus, but also in other countries with the help of the MIT OpenCourseWare - a project of the Massachusetts Institute of Technology to publish freely available materials from all university courses; MITx - a program allowing you to publish a videos on the platforms of massive open online courses; MicroMasters - a series of online courses whose purpose is to study in depth the basic disciplines: Microeconomics, Data Analysis for Social Scientists, and Designing and Running Randomized Evaluations, Economic Development etc., which allows you to successfully pass the exam and to apply to MIT's new Master's program in Data, Economics, and Development Policy. Based on the analysis of the curricula offered at the Department of Economics, the competencies of graduates-economists at the Massachusetts Institute of Technology are summarized.

Keywords: economic education, Department of Economics, information and communication technologies, professional disciplines, professional training, pedagogical approaches, interactive teaching methods.

Вступ. Тенденції розвитку економічної освіти Сполучених Штатів Америки свідчать про підвищення значущості економічної грамотності американського суспільства, посилення уваги до вищої економічної та бізнес-освіти з боку уряду, громадськості й керівництва закладів освіти, а також про збільшення потреби США у кваліфікованих кадрах економічного профілю.

США $є$ одним із світових лідерів у галузі освіти. У країні успішно функціонує близько чотирьох тисяч закладів вищої освіти, зокрема 
Стенфордський, Гарвардський, Каліфорнійський, Принстонський університети.

Окремої уваги заслуговує Массачусетський технологічний інститут (MTI), мета діяльності якого визначена як «просування знань у науці, техніці та інших галузях, які будуть найкраще служити нації та всьому світу в XXI столітті» (Massachusetts Institute of Technology, 2020). Понад 120 тис. випускників Массачусетського технологічного інституту досягли значних успіхів у наукових пошуках, державній службі, освіті та бізнесі. Станом на грудень 2019 року, 39 випускників МТІ отримали Нобелівську премію. Випускники MTI заснували безліч відомих компаній, таких як Intel, McDonnell Douglas, Texas Instruments, Qualcomm, Apotex, Koch Industries, Rockwell International, Genentech, Dropbox, Campbell Soup та ін.

Установлено, що на актуальності економічної освіти наголошували відомі випускники МТI. Так, Престон Макафі (Preston McAfee) - головний економіст корпорації Microsoft та Google, науковий співробітник Yahoo, професор факультету економіки Массачусетського технологічного інституту, зауважував, що майбутній економіст повинен поєднувати вивчення теорії 3 iï практичним застосуванням: «Необхідно використовувати економічні принципи і економічну теорію, але, також, у своїй діяльності необхідно проводити експерименти, застосовувати статистичні дані та інші аспекти практичної економіки для створення діючих систем, які витримають випробування часом» (Massachusetts Institute of Technology, 2020).

Доповнюючи зазначену точку зору, С'юзен Ейті (Susan Athey) консультант Microsoft, доцент кафедри кар'єрного розвитку MTI, професор Стенфордської вищої школи бізнесу стверджує, що економісти повинні вміти аналізувати великий обсяг даних за допомогою інформаційнокомунікаційних технологій, пояснюючи це тим, що більшість технологічно розвинених корпорацій пов’язують інженерну роботу з бізнесом: «Успішний економіст багатомовний - він набуває навичок у сфері фінансів та бізнесу, але він, також, володіє технічними аспектами ведення бізнесу» (Massachusetts Institute of Technology, 2020).

Випускник МТI Майкл Бейлі (Michael Bailey) - менеджер із економічних досліджень Facebook Inc, переконаний, що існує відмінність наукової та економічної діяльності так само як різниця між широтою та глибиною: «У сфері реальної економіки ви працюєте над більш широким спектром проєктів, де застосовується міждисциплінарний підхід» (Massachusetts Institute of Technology, 2020). Водночас, Хел Варіан (Hal Varian) - випускник 
MTI, заслужений професор Каліфорнійського університету, головний економіст Google, підтримує думку Бейлі: «Спільнота людей, що використовує міждисциплінарний підхід у сфері економіки, значно зросла 3 незначної кількості до сотень у наукових колах, бізнесі, уряді за останні 10 років» (Massachusetts Institute of Technology, 2020).

Установлено, що питання економічної освіти студентів вивчали як зарубіжні дослідники - А. Абаді, Д. Ацемоглу, Х. Варіан, П. Макафі, С. Ейті, Г. Ангелетос, М. Бейлі (Chen, 2016; Massachusetts Institute of Technology, 2020), так і вітчизняні - Л. Огнівко (Ohnivko, 2011), О. Наугольникова (Nauholnykova, 2013), Б. Дуб (Dub, 2012), Д. Антонюк (Antonyuk, 2016), В. Ільїна (Ilyina, 2009) та ін.

Зважаючи на тривалий досвід підготовки висококваліфікованих фахівців, управлінців та науковців у галузі економіки, накопичений у MTI, можливості сучасних інформаційно-комунікаційних технологій та нагальні потреби реформування вітчизняної системи економічної освіти, необхідним $\epsilon$ визначення можливостей та шляхів використання цього досвіду в освітній галузі України.

Мета та завдання. Мета статті - визначити особливості процесу професійної підготовки майбутніх фахівців на економічному факультеті Массачусетського технологічного інституту.

Методи дослідження. Під час наукового пошуку застосовано ряд загальнонаукових методів дослідження, а саме: аналіз, синтез, систематизація, класифікаиія, індукиія, дедукція - для визначення теоретичних закономірностей педагогічної діяльності економічного факультету Массачусетського технологічного інституту; моніторинг сучасних освітніх програм економічного факультету; сходження від абстрактного до конкретного - для узагальнення моделі економічної освіти Массачусетського технологічного інституту.

Результати. Досвід діяльності МТI переконливо свідчить про те, що формування людського капіталу, освіта та професійна підготовка економістів відіграють важливу роль у конкурентоздатності Сполучених Штатів Америки як на континентальному, так і на світовому рівні (Massachusetts Institute of Technology, 2020).

За даними офіційного сайту МТI, його професорсько-викладацький склад становить понад 1000 осіб - це, зокрема, висококваліфіковані асистенти, викладачі, доценти, професори у галузях математики, фізики, штучного інтелекту, економіки, менеджменту, мистецтва та медіа, 
архітектури, астрономії, біології та медицини, електротехніки, інженерії, машинобудування, історії, лінгвістики, літератури, філософії, політології тощо.

Контингент студентів та аспірантів інституту станом на вересень 2019 року становив 11520 осіб, що вважається досить незначною кількістю для американського вишу, котрий є одним із лідерів у галузі вищої освіти. Поряд із цим, установлено, що кожен зі студентів інституту має можливість набувати, генерувати і удосконалювати знання та навички, а випускники здатні розробляти фундаментальні технології, відкривати нові галузі та забезпечувати створення мільйонів робочих місць (Massachusetts Institute of Technology, 2020).

3'ясовано, що структура МТI складається 3 п'яти окремих підрозділів: школа архітектури та планування; школа інженерії; школа науки; школа менеджменту; школа гуманітарних, художніх і соціальних наук. МТI у своїй структурі нараховує 30 факультетів, 53 міждисциплінарні лабораторії, коледж комп'ютерних технологій імені Стівена Аллена Шварцмана, метою діяльності якого $є$ вирішення проблем розробки якісних технологій штучного інтелекту та обчислювальних приладів для різних галузей народного господарства (Massachusetts Institute of Technology, 2020; Ohnivko, 2011).

Варто відзначити той факт, що економічний факультет (Department of Economics) MTI вже багато десятиліть відіграє провідну роль у галузях економічної освіти та державної служби. Вивчення історії розвитку економічного факультету, показало, що у кінці XIX ст. завдяки діяльності Френсіса Амаса Уокера (Francis Amasa Walker) - провідного економіста свого часу, члена Національної академії наук США (1878), засновника і першого президента Американської економічної асоціації (1886-1892), було розпочато підготовку студентів бакалаврату. За сприяння Девіса Річа Дьюї (Davis Rich Dewey) - професора економіки та декана економічного факультету MTI, у 1937 р. при економічному факультеті MTI була відкрита магістратура з економіки, а у 1941 році була відкрита програма $\mathrm{PhD}$.

Серед випускників економічного факультету МТI були викладачі Гарвардського, Йельського, Принстонського університетів, Військової академії США, лауреати Нобелівської премії, стипендіати Національної академії наук США та Економетричного співтовариства (Massachusetts Institute of Technology, 2020).

Установлено, що сьогодні економічний факультет МТI ставить перед собою такі завдання: 
- формування у здобувачів освіти навичок прогнозування мікро- i макроекономічних явищ та процесів;

- формування умінь вирішувати проблеми задоволення потреб в умовах дефіциту ресурсів;

- розвиток здатності аналізувати наслідки впливу економічної кон'юнктури на діяльність підприємців, державних установ та неприбуткових організацій;

- розвиток умінь приймати ефективні рішення, не порушуючи при цьому внутрішніх та зовнішніх економічних інтересів (Massachusetts Institute of Technology, 2020; Nauholnykova, 2016).

Зважаючи на особливості професійної підготовки студентів 3 економічних спеціальностей, у МТІ базовим періодом підготовки бакалаврів (Undergraduate level) є чотирьохрічне навчання, після успішного закінчення якого, присвоюється освітній ступінь (Ilyina, 2009; Massachusetts Institute of Technology, 2020; Nauholnykova, 2016; Oliynyk, 2016).

Установлено, що впродовж перших двох семестрів навчання студенти вивчають теоретичні та прикладні дисципліни з мікро- і макроекономіки та статистики. Впродовж наступних семестрів навчальним планом передбачено засвоєння дисциплін вузьких спеціалізацій (majors), одну з яких студенти можуть обирати самостійно 3 широкого переліку предметів (інформатика, економіка та наука про дані, економічна теорія, математична економіка тощо).

Аналіз змісту підготовки економічних кадрів в MTI за освітнім рівнем «бакалавр» показав, що в залежності від спеціалізацій передбачено вивчення та засвоєння таких дисциплін: мікроекономіка, макроекономіка, політична економія, лінійна алгебра, дискретна математика, теорія ймовірності, статистика, наука про дані, принципи мікро- та макроекономіки, державна політика, економічне застосування теорії ігор, дизайн ринку, економікоматематичне моделювання, фінансові ринки, статистичні методи в економіці, економіка енергетики, поведінкова економіка, міжнародна торгівля тощо (Ilyina, 2009; Massachusetts Institute of Technology, 2020; Nauholnykova, 2013; Nauholnykova, 2016; Oliynyk, 2016).

Вивчення досвіду діяльності МТI показало, що навчання майбутніх випускників-бакалаврів економічним дисциплінам здійснюється на основі таких педагогічних підходів:

- традиційний підхід «Chalk and Talk» (традиційні лекції); 
- професійний підхід «Proficiency Approach» (проведення практичних занять у формі семінарів, лабораторних робіт тощо);

- проблемний підхід «Peakonomics» (використання проблемних ситуацій у процесі викладання базових економічних концепцій);

- письмовий підхід «Writing Intensive» (інтегрування до навчальних програм з економіки письмових робіт для залучення студентів до більш детального вивчення матеріалу);

- мотиваційний підхід «Attention, Relevance, Confidence, and Satisfaction» (оптимізація елементів мотивації для поліпшення впливу викладання) (Nauholnykova, 2013; Oliynyk, 2016).

Установлено, що на відміну від України, де основними видами контролю навчальної діяльності студентів $є$ виконання контрольних, лабораторних, самостійних та індивідуальних робіт, у МТІ передбачено виконання одного або декількох творчих завдань у залежності від навчальної дисципліни.

Варто зазначити, що студенти можуть навчатися за різними варіаціями кількості предметів і тривалості їх вивчення. При складанні освітніх програм та навчальних планів до уваги приймаються тенденції розвитку світового ринку праці, залучаються потенційні роботодавці для впровадження найважливіших практичних елементів у навчання майбутніх фахівців економічного профілю (Ilyina, 2009).

У американській академічній спільноті панує уявлення про майбутнього економіста не лише як вправного працівника, а й як представника особливої, самостійної професії, котра вимагає спеціальної освіти високого рівня, глибоких знань i навичок. Саме через це, у США диплом бакалавра вважається недостатнім для отримання високих посад у фінансовоекономічній галузі, для цього претендент на посаду повинен мати магістерський ступінь (Graduate level).

Університет пропонує магістерську програму у галузі економіки та політики розвитку (Master program in Economics, and Development Policy $M E D P)$. Виходячи 3 аналізу навчальної програми $M E D P$, можна стверджувати, що вона поєднує в собі як очну форму навчання, так і дистанційну у рамках програми MITx MicroMasters.

Для організації дистанційного навчання студентів, економічний факультет МТІ спільно 3 Лабораторією дій у боротьбі з бідністю імені Абдула Латіфа Джаміля (Abdul Latif Jameel Poverty Action Lab, J-PAL) науково-дослідним центром для проведення вимірювань у галузях сільського 
господарства, охорони здоров'я, управління та освіти, розробили онлайнплатформу MicroMasters. Метою створення цієї платформи є організація процесу оволодіння студентами теоретичними знаннями та практичними навичками для вирішення нагальних проблем, з якими стикаються найменш розвинені країни світу. Запропонований на платформі навчальний курс, складається 3 п’яти онлайн-занять та іспиту. У результаті оволодіння навчальним курсом, здобувачі оперують знаннями в галузі мікроекономіки, економічного розвитку, статистики та теорії ймовірності, а також залучаються до передових наукових досліджень 3 економіки. Варто зазначити, що викладачами онлайн-курсу є видатні професори та науковці, наприклад, Естер Дюфло (Esther Duflo) і Абхіджіт Банерджі (Abhijit Banerjee) - лауреати Нобелівської премії з економічних наук 2019 року.

3'ясовано, що під час навчання за програмою DEDP MicroMasters, здобувачі опановують трьома базовими курсами (мікроекономіка, аналіз даних для соціальних вчених, розробка і проведення рандомізованих оцінок) та двома вибірковими із трьох запропонованих (проблеми глобальної бідності, основи політики розвитку, політична економія i економічний розвиток). Варто зазначити, що всі навчальні курси можуть вивчатись у будьякій послідовності. Здобувачі, котрі успішно склали іспити програми MicroMasters, мають право подати заявку на вивчення основної магістерсьої програми MTI у галузі економіки та політики розвитку. Магістранти отримають додаткові кредити за курси, якими вони оволоділи у програмі MicroMasters, що надає їм можливість здобути ступінь магістра в МТI достроково.

Очна частина курсу передбачає вивчення дисциплін у галузі мікроекономіки (мікроекономічна теорія, поведінкова економіка, теорія ігор тощо), економіки розвитку (політична економія, економіка оточуючого середовища тощо), аналізу даних (економетрика, оцінка програми тощо). Студенти також мають відвідувати щотижневий ланч-семінар, призначений виключно для магістерської програми DEDP. Магістранти можуть відвідувати відомчі дослідницькі семінари 3 економіки розвитку, які зосереджуються на обговоренні наукових досліджень і політичних питань (Dub, 2012; Massachusetts Institute of Technology, 2020).

Варто зазначити, що студенти MTI повинні проходити обов'язкову практичну підготовку. Метою практики є застосування теоретичних знань, отриманих під час навчання. Практика передбачає спеціально розроблену 
програму стажування та надання звіту про ऑii виконання (Massachusetts Institute of Technology, 2020; Nauholnykova, 2016).

Особливістю освітніх програм MTI з підготовки бакалаврів та магістрів з економіки є те, що значна увага приділяється використанню інтерактивних методів навчання («case study», ділові ігри, господарські ситуації, робота над реальними проєктами державних службовців чи приватних корпорацій). Метою впровадження інтерактивних методів навчання $\epsilon$ формування у студентів умінь і навичок самостійного прийняття економічних рішень, вивчення спеціалізованих курсів за вибором, розв'язання питання зв'язку теорії з економічною практикою чи бізнесом, жорсткого контролю знань i успішності, а також сучасних економічних питань, (Dub, 2012; Massachusetts Institute of Technology, 2020; Nauholnykova, 2013; Nauholnykova, 2016; Ohnivko, 2011).

Ключовим моментом навчання фахівців економічної спеціальності в MTI є широке використання можливостей мережі Інтернет. На веб-сайті економічного факультету представлена актуальна інформація щодо курсів та семінарів. Сайт пропонує здобувачам посилання на веб-сторінки, де викладачі публікують програмні документи, онлайн-підручники, проводять вебінари тощо. Більшість начальних занять, пропонованих викладачами економічного факультету, також доступні в мережі Інтернет. Таку можливість надала реалізація відкритого курсу MIT OpenCourseWare (ocw.mit.edu) - проєкт MTI з публікації у вільному доступі матеріалів усіх курсів університету.

Опубліковані матеріали містять плани курсів, конспекти лекцій, домашні завдання, екзаменаційні питання. Більшість курсів пропонують доступні відеозаписи лекцій. Ще однією Інтернет-інновацією інституту $є$ MITx - програма масових відкритих онлайн-курсів, у рамках якої викладачами публікуються відеоматеріали, що розміщуються на МВОКплатформі $e d X$. Для прикладу, на платформі у вільному доступі розміщені лекції за такими темами: «Проблеми глобальної бідності» (2013), «Основи політики розвитку: економіка передового розвитку» (2015), «Принципи мікроекономіки» (2016), «Аналіз даних для соціальних вчених» (2016) тощо (Antonyuk, 2016; Dub, 2012; Massachusetts Institute of Technology, 2020; Nauholnykova, 2016).

Окремої уваги потребує вивчення докторської програми (PhD) Массачусетського технологічного інституту з економіки, що є невід'ємною складовою професійної кар'єри у США. Установлено, що докторська 
програма передбачає навчання впродовж п’яти років, під час яких здобувач повинен:

- продемонструвати високий рівень компетентності в основних галузях економічної теорії, статистики та економетрики за допомогою загальних i курсових іспитів;

- продемонструвати компетентність 3 чотирьох навчальних предметах, 3 яких два - визначені як основні, а інші два - другорядні;

- представити і захистити дисертацію, яка передбачає істотний внесок у розвиток економічної теорії та практики.

Зазначимо, що перші два роки навчання на докторських програмах передбачають оволодіння двома основними предметами з економіки та двома додатковими. Сьогодні факультет пропонує одинадцять навчальних предметів за вибором: економічна теорія, економічний розвиток, економетрика, приватні та державні фінанси, промислові організації, міжнародна економіка, економіка праці, макроекономіка, організаційна економіка, політична економія.

Після успішного складання іспитів з усіх предметів, здобувач має право розпочинати наукові пошуки, метою яких $\epsilon$ написання дисертації, що демонструє уміння здобувача проводити самостійні наукові дослідження, а також визначати актуальність теми і використовувати необхідні аналітичні інструменти. Написання дисертації відбувається під керівництвом наукового консультанта, який повинен надати письмовий відгук про роботу. Для захисту дисертації доктора філософії складається комісія 3 трьох осіб науковий консультант та незалежні експерти.

Навчання на докторських студіях MTI супроводжується відвідуванням спецсемінарів за участі запрошених фахівців із різних галузей, які пропонують здобувачам ознайомитись із останніми науковими дослідженнями. На відміну від більш формального характеру семінарів, $є$ щотижневі неформальні «польові обіди» (field lunches). Метою таких обідів $є$ консультування здобувачів щодо питань наукового дослідження. Під час таких заходів молоді вчені, що склали загальні іспити, презентують свої дослідницькі ідеї, починаючи із самих ранніх етапів дослідження, i, закінчуючи фактично завершеними дисертаційними проєктами. Неформальність цих зустрічей дозволяє здобувачам обговорювати етапи наукових досліджень у вільній атмосфері (Massachusetts Institute of Technology, 2020). 
Установлено, що результатом економічної підготовки у MTI $\epsilon$ формування у здобувачів вищої освіти таких компетентностей:

- компетентності у сфері економічної діяльності (економічне мислення, володіння методами економічного і статистичного аналізу, прогнозування економічної діяльності, прийняття управлінських рішень на мікро- та макрорівні тощо);

- професійно-орієнтовані компетентності (система знань 3 економічного аналізу, фінансів, аудиту, статистики, міжнародної економіки, правознавства, маркетингу, менеджменту тощо);

- інформаційні компетентності (ефективне застосування інформаційно-комунікаційних технологій та спеціалізованих програм);

- комунікативні компетентності (толерантність, знання ділового етикету та основ конфліктології, командна взаємодія, активна життєва позиція тощо);

- особистісні компетентності (адекватна самооцінка, впевненість у собі, самоконтроль, стресостійкість, вимогливість, оперативність, концентрація на деталях, уміння визначати пріоритети, високий рівень мотивації до досягнень, визнання необхідності освіти протягом життя) (Oliynyk, 2016).

Обговорення. Проведений аналіз щодо особливостей професійної підготовки студентів на економічному факультеті МТI тісно перетинається 3 дослідженнями низки зарубіжних учених, заслужених економістів, випускників та професорів університетів, таких як: А. Абаді, Д. Ацемоглу, Х. Варіан, П. Макафі, С. Ейті, Г. Ангелетос, М. Бейлі (Chen, 2016; Massachusetts Institute of Technology, 2020). На жаль, публікації пострадянських дослідників, як-от: Л. Огнівка щодо професійної підготовки магістрів економічного профілю у закладах освіти США (Ohnivko, 2011), О. Наугольникової, яка стосується становлення і розвитку вищої економічної освіти в США (Nauholnykova, 2013), Б. Дуба, що ілюструє досвід США у вищій економічній освіті (Dub, 2012), Д. Антонюка, котра розкриває зарубіжний досвід використання програмно-імітаційних комплексів економічного спрямування в освіті (Antonyuk, 2016), В. Ільїної, що демонструє становлення та розвиток вищої економічної і бізнес-освіти США у сучасних умовах (Ilyina, 2009), охоплюють, здебільшого, загальну систему економічної освіти Сполучених Штатів Америки та лише фрагментарно демонструють особливості діяльності окремих закладів освіти (Гарвардського, Стенфордського, Каліфорнійського, Мічиганського та ін. 
університетів). Проте, за даними вищезазначених досліджень вдалось встановити мету та завдання діяльності економічного факультету щодо підготовки економістів, визначити освітні ступені підготовки, узагальнити особистісні та фахові компетенції, розкрити особливості інтерактивного та дистанційного навчання тощо.

Висновки. Отже, досвід MTI показує, що сучасна економічна освіта США передбачає оволодіння освітніми ступенями бакалавра (Undergraduate level), магістра (Graduate level) та доктора філософії (PhD). Підготовка фахівців економічного профілю полягає у вивченні таких дисциплін, як: політична економія, мікро- та макроекономіка, теорія ймовірності, статистика, економіко-математичне моделювання, економічне застосування теорії ігор, фінансові ринки, маркетинг, економічний розвиток, міжнародна економіка та багато інших. Серед провідних методів навчання визначено інтерактивні методи («case study», ділові ігри, господарські ситуації, робота над бізнес-проєктами, ланч-семінари, польові обіди тощо).

Здобувачі вищої освіти навчаються за очною та дистанційною формами навчання. Характерною рисою дистанційного навчання фахівців $\epsilon$ використання Інтернет-мережі і проєктів MIT OpenCourseWare, MITx та MicroMasters.

Доведено, що досвід американської економічної освіти доцільно використовувати в Україні у площині використання провідних підходів до підготовки фахівців 3 економіки 3 урахуванням національних освітніх традицій, впровадження заходів інтернаціоналізації навчального процесу у вітчизняних закладах вищої освіти та підвищення ролі інформаційнокомунікаційних технологій у системі економічної освіти.

\section{ЛIТЕРАТУРА:}

Julia Chen. Economists Adding Up At Amazon.com, Microsoft, Google. Investor's Business Daily. Los Angeles, 2016. Retrieved from: https://www.investors.com/news/technology/amazon-microsoft-among-techs-that-saye mploying-economists-adds-up.

Massachusetts Institute of Technology. The official website Massachusetts Institute of Technology. Retrieved from: http://web.mit.edu/.

Massachusetts Institute of Technology. Wikipedia. 2020. Retrieved from: https://en.wikipedia.org/wiki/Massachusetts_Institute_of_Technology.

Антонюк Д. С. Зарубіжний досвід використання програмно-імітаційних комплексів економічного спрямування в освіті. Інформаційні технологї в освіті. 2016. Вип. 2. C. $140-153$.

Дуб Б. С. Зарубіжний досвід вищої економічної освіти: приклад США. Міждисииплінарні дослідження в науйі. 2012. № 1. Режим доступу: http://uchni.com.ua/ekonomika/4157/index.html. 
Ільїна В. Ю. Становлення та розвиток вищої економічної і бізнес-освіти Сполучених Штатів Америки у сучасних умовах. Автореф. дис... канд. пед. Наук. 13.00.01 загальна педагогіка та історія педагогіки. Ялта, 2009. - 20 с.

Наугольникова О. М. Система професійної підготовки майбутніх економістів у США. Педагогіка та психологія. 2016. Вип. 52. С. 291-301.

Наугольникова О. М. Становлення і розвиток вищої економічної освіти в США. Проблеми сучасної педагогічної освіти. Серія: «Педагогіка і психологія». 2013. Вип. 39(2). С. 134-138.

Огнівко Л. В. Професійна підготовка магістрів економічного профілю у вищих навчальних закладах США. Збірник наукових пращь Хмельнищького інституту соиіальних технологій Університету «Украӥна». 2011. № 3. С. 135-139.

Олійник О. В. Особливості підготовки бакалаврів з економіки та бізнес-освіти у вищих навчальних закладах США. Модернізація структури та змісту економічної освіти на засадах компетентнісного підходу : матеріали наук.-метод. семінару викл. екон. ф-ту ХНПУ ім. Г. С. Сковороди. Харків : ХНПУ, 2016. С. 80-92.

\section{REFERENCES:}

Antonyuk, D. S. (2016). Zarubizhnyy dosvid vykorystannya prohramno-imitatsiynykh kompleksiv ekonomichnoho spryamuvannya $\mathrm{v}$ osviti [Foreign experience in the use of software and simulation systems of economic orientation in education]. Informatsiyni tekhnolohiyi $v$ osviti, 2, 140-153 (in Ukrainian).

Chen, J. (2016) Economists Adding Up At Amazon.com, Microsoft, Google. Investor's Business Daily. Retrieved from: https://www.investors.com/news/technology/amazon-microsoftamong-techs-that-saye mploying-economists-adds-up

Dub, B. S. (2012). Zarubizhnyy dosvid vyshchoyi ekonomichnoyi osvity: pryklad USA [Foreign experience of higher economic education: the example of the United States]. Mizhdystsyplinarni doslidzhennya $v$ nautsi, 1. Retrieved from: http://uchni.com.ua/ekonomika/4157/index.html/ (in Ukrainian).

Ilyina, V. Yu. (2009). Stanovlennya ta rozvytok vyshchoyi ekonomichnoyi i biznes-osvity Spoluchenykh Shtativ Ameryky u suchasnykh umovakh [Formation and development of higher economic and business education in the United States of America in modern conditions]. (Extended abstract of candidate's thesis). Republican Higher Educational Institution «Crimean Humanities University». Crimea (in Ukrainian).

Massachusetts Institute of Technology. (2020). The official website Massachusetts Institute of Technology. Retrieved from: http://web.mit.edu/

Massachusetts Institute of Technology. (2020). Wikipedia. Retrieved from: https://en.wikipedia.org/wiki/Massachusetts_Institute_of_Technology.

Nauholnykova, O. M. (2016) Systema profesiynoyi pidhotovky maybutnikh ekonomistiv u USA [The system of professional training of future economists in the USA]. Pedahohika ta psykholohiya, 52, 291-301 (in Ukrainian).

Nauholnykova, O. M. (2013) Stanovlennya i rozvytok vyshchoyi ekonomichnoyi osvity v USA [Formation and development of higher economic education in the USA]. Problemy suchasnoyi pedahohichnoyi osvity. Seriya: «Pedahohika i psykholohiya», 39, 134-138 (in Ukrainian).

Oliynyk, O. V. (2016). Osoblyvosti pidhotovky bakalavriv z ekonomiky ta biznes-osvity u vyshchykh navchal'nykh zakladakh USA [Peculiarities of preparation of bachelors in economics and business education in higher educational institutions of the USA]. Modernizatsiya struktury ta zmistu ekonomichnoyi osvity na zasadakh kompetentnisnoho pidkhodu : materialy nauk.-metod. seminaru vykl. ekon. f-tu KhNPU im. H. S. Skovorody [Modernization of the structure and content of economic education on the basis of the 
competence approach : materials of the scientific methodical seminar of teachers of the economic faculty of H. S. Skovoroda Kharkiv National Pedagogical University]. Kharkiv (in Ukrainian).

Ohnivko, L. V. (2011). Profesiyna pidhotovka mahistriv ekonomichnoho profilyu u vyshchykh navchal'nykh zakladakh USA [Professional training of masters of economic profile in higher educational institutions of the USA]. Zbirnyk naukovykh prats Khmelnytskoho instytutu sotsialnykh tekhnolohiy Universytetu «Ukrayina», 3, 135-139 (in Ukrainian)

\begin{tabular}{ll}
\multicolumn{1}{c}{ Інформація про автора: } & \multicolumn{1}{c}{ Information about the author: } \\
Сотніков Дмитро Володимирович & Sotnikov Dmytro Volodymyrovych \\
ORCID: https://orcid.org/0000-0001-5740- & ORCID: https://orcid.org/0000-0001-5740- \\
5808; аспірант кафедри історії педагогіки і & 5808; PhD Student of Department of history of \\
порівняльної педагогіки, Харківський & pedagogy and comparative pedagogy, H. S. \\
національний педагогічний університет & Skovoroda Kharkiv National Pedagogical \\
імені Г. С. Сковороди, вул. Валентинівська, & University, Valentynivska street, 2, Kharkiv, \\
2, м. Харків, Україна, 61000. & Ukraine, 61000. \\
& \\
e-mail: sotnickov.dmitry@gmail.com & e-mail: sotnickov.dmitry@ gmail.com
\end{tabular}

Цитуйте цю статтю як: Сотніков Д.В. Особливості діяльності економічного факультету Массачусетського технологічного інституту. Теорія та методика навчання та виховання. 2020. № 48. C. 109-122.

DOI: https://doi.org/10.34142/23128046.2020.48.10

Дата надходження статті до редакції:

Стаття прийнята до друку: 